\title{
Heat shock protein (HSP) release mechanism under heat stress pressure in Goats: a review
}

\author{
Rafika Febriani Putri $^{1}$, Tri Eko Susilorini ${ }^{1}$, Nashi Widodo $^{2}$, Kuswati Kuswati $^{1}$ and Suyadi \\ Suyadi ${ }^{1, *}$ \\ ${ }^{1}$ Faculty of Animal Science, Universitas Brawijaya, Malang, Indonesia \\ ${ }^{2}$ Department of Biology, Faculty of Mathematics and Natural Sciences, Universitas Brawijaya, \\ Malang, Indonesia
}

\begin{abstract}
Among the various climate variables, heat stress has been reported to be the most detrimental factor to the economy of the livestock industry. Heat stress is one of the most stressful events in the life of livestock with harmful consequences for animal health, productivity and product quality. Heat shock proteins (HSPs), also known as molecular chaperons, are prominent stress markers. Heat shock proteins consist of highly conserved protein expressed at the time of stress, and play an important role in adaptation to the environmental stress. This review discusses the scientific evidence regarding the effects of heat stress and role of HSP during heat stress on Goats.
\end{abstract}

\section{Introduction}

Goats have been widely used as livestock models in recent climate research. They have better thermotolerance [1], ability to survive on limited pastures, as well as their disease resistance capacity. Goats easy to mantain and can live well, even by consuming shrubs and other poor quality fiber, because goats are able to digest crude fiber [2, 3]. Rearing goats is considered more economical than large ruminants in many studies on climate change related to feed and fodder availability. Goat populations living under harsh environments have a wide diversity of traits. This proves that various environmental conditions can have different effects on goat productivity [4].

Indonesia is a tropical country because it is located on the equator. This condition causes Indonesia to experience heat throughout the year with relatively high temperatures. It can affect negatively thermoneutral zone of the animals.

Goat can easily exposed by various stress, like physical, nutritional and heat stress. Of all, heat stress is the most worrisome due to decreased in livestock performance, as well as natural immunity. Heat stress make livestock more susceptible to disease and even death. Thus, economic losses are unavoidable due to heat stress $[5,6]$.

When cattle are stressed, the body will maintain homeostasis through physiological mechanisms including endocrine responses and cellular heat stress responses [7]. During

\footnotetext{
* Corresponding author: suyadi@ub.ac.id
} 
thermal stress, the body's resources including protein and energy was used to maintain homeostatis by expense the declining growth, reproduction, production, and health.

Heat shock proteins (HSPs) are responsible for maintaining the balance in organism, to acclimatize the stress and these proteins regulated Cellular tolerance to heat stress. HSPs are released intra and extra cellularly in response to various environmental stresses $[8,9]$, beside that HSPs can be an indicator of stress in cells.

Hsp70 has a significant role in cell thermo tolerance and animal survival than other HSP family. The heat stress regulation at cellular and molecular level, include the expression pattern of Hsp70 gene was very important to understand, because it can describe the mechanism of heat stress and role of Hsp70 during heat stress adaptation in goats [10, 11].

\section{Heat shock protein (HSP) and its function}

Heat shock proteins (HSPs) are a specific family of proteins produced by cells, and protect the cell from damage in response to stress conditions. Subsequent studies have shown that this protein is also produced as a result of other conditions in the organism such as ultraviolet radiation [12], temperature fluctuations [13], as well as during wound healing and tissue regrowth [14].

Most of this family member act as molecular binders between the cell and some proteins in the membrane and prevent the formation of newly formed proteins to maintain their vital roles. Heat shock protein plays an important role when high temperature has an adverse effect on cell structure and cell physiology [15].

[16] noted that HSPs are various proteins that act to protect cells from different stress conditions and are classified according to their molecular weight. [17] have reported that the importance of HSPs was their direct involvement in all important protein-related processes such as protein secretion, synthesis and prevention of degradation, as well as regulation of replication processes.

\section{Mechanism of HSP synthesis and release}

The mechanism of action of HSPs is directly related to heat shock factor (HSF) which occurs in almost all organisms, especially in livestock. [18] demonstrated that HSF acts as a transcription factor with the gene responsible for HSP. When cells are exposed to different stress conditions, HSP genetic expression is induced.

Increased expression of these genes is considered a response to stress through various genetic and biochemical processes referred to as HSR [19]. Heat shock proteins have different molecular weights as measured by Dalton. These proteins are called HSP60, HSP70 and HSP90 [20]. 


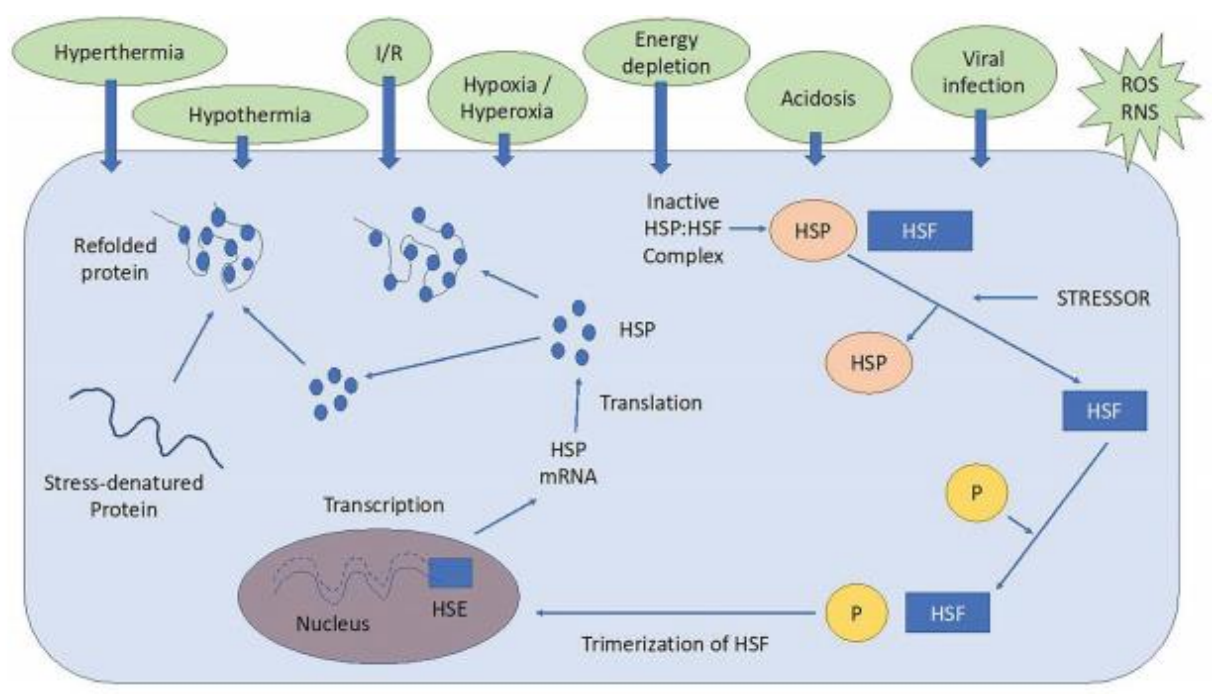

Fig. 1. Molecular Mechanism of Heat Shock Protein (HSP) Synthesis [2].

In the cytosol, the HSP connect each other with heat shock factors (HSF) to maintain an inactive state (Figure 1). Stimulation by heat stressors (HS) make HSF actived. It caused the bond between HSP and HSF is severed. Then, trimer complex (The HSF that are phosphorylated by protein kinases) will enter the nucleus and bind with heat shock elements (HSE). From the process of transcription, HSP70 mRNA was formed. The new HSP70 will be synthesised after leaves the nucleus. The newly synthesised HSP serving as a molecular chaperone. Then, facilitating the formation of new proteins within the cell. The newly synthesised HSP also repairing and refolding damaged proteins when heat stress occured [21].

\section{HSPs during heat stress in goats}

Stress could be defined as body's reaction to external influences that disrupt homeostasis, can affect on health and performance [22]. Small ruminant owners must be faced by climate change effects that impact to animal health and production [23, 24]. According to [24] heat stress is a problem that will continue to increase in the near future due to the development of global warming.

[25] define heat stress in which the physiological mechanisms of the animal's body are activated to maintain thermal balance, when animal was exposed by high temperatures. The effect of heat stress various on livestock according to species, growth phase, even the nutritional status. [26]. 


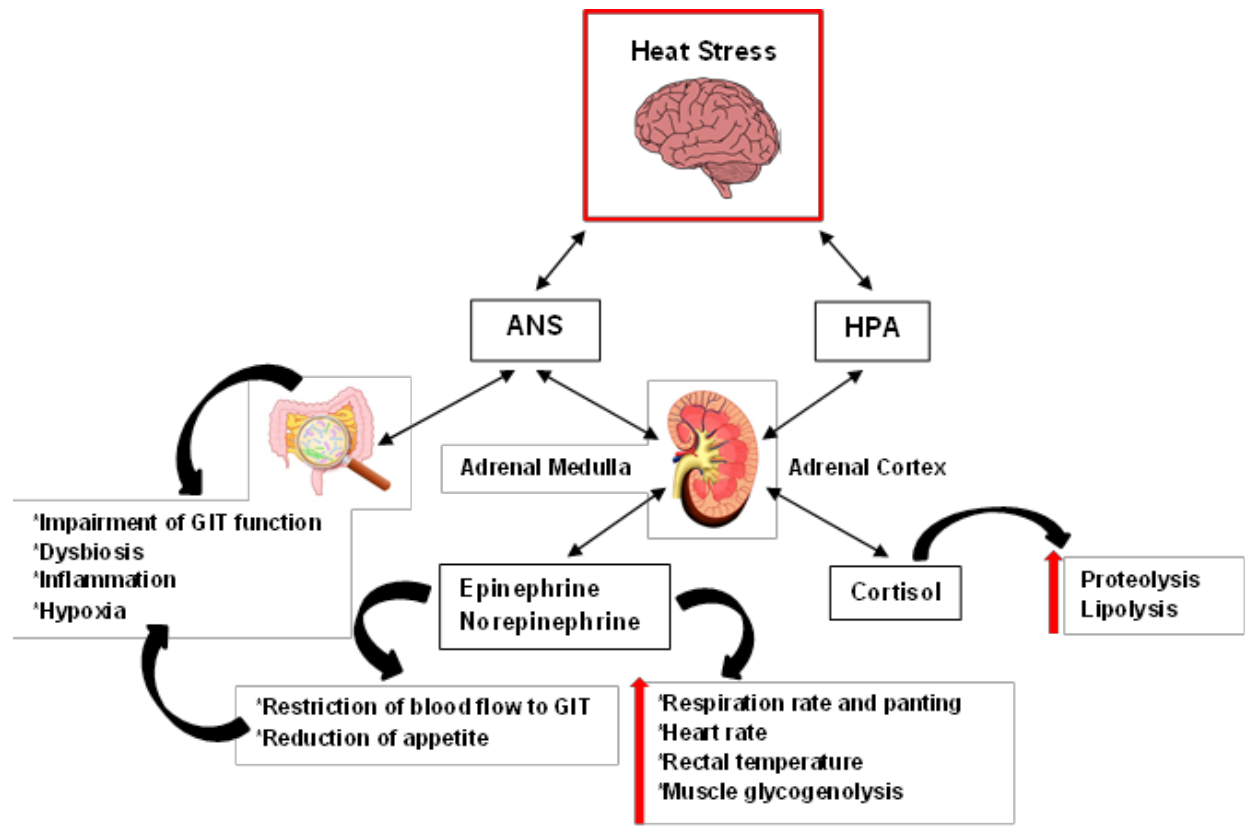

Fig. 2. Impact of Heat Stress to the Autonomic Nervous System (ANS) and the HypothalamicPituitary-Adrenal (HPA) Axis [27].

Heat stress affects the all of animal's body, from their hematological until biochemical parameters [28-31]. It also negatively affects their production, growth, and natural immunity. When heat stress occured, goats more susceptible to disease and even death [31].

Heat shock protein 70 (HSP70) is used as a biomarker of cellular stress. Their expression level can show of duration of heat stress.

Heat stress denatures proteins and alters translation. Heat exerts a complex effect on autophagy [33]. Autophagy helps cell to adapt during heat stress by facilitating correct folding in response of cell adaptation [34, 35].

[36] reported that HSP70 gene expression was higher in PBMC of tropical goats during the summer season. HSP response was found in the liver and kidney of Barbari gaots which implies that higher expression of HSP70 at the tissue level protects the cells damage [36]. [38] showed that a higher expression of HSP70 also found in the kidney and heart of goats during another stress factor occured. [39] reported the lower expression of HSP genes in sheep revealed the possibility of highest adaptability. Further, [40] observed higher expression of HSP90AA1 gene during chronic heat stress while reported reduced expression of HSPA1 A and HSPA8 during summer season in Chokla, Magra, Marwari, and Madras Red sheep breeds. Seasonal variation was also established for the expression pattern of HSP70 gene family in Sirohi, Barbari, Gaddi and Chegu breeds of goats adapted to different agro climatic conditions [41]. Similarly, [42] also observed over expression of HSP90AA1 G/C-660 and A/G444 in heat stressed Manchego Spanish sheep. 


\section{HSPs and the comfort zone}

The thermoneutral zone of ruminants is the optimal temperature range in which no additional energy above maintenance is required for thermoregulation. If environmental factors increase beyond the limits of the thermoneutral zone, the body will adapt. The process of heat loss occurs when the core body temperature increases, the ambient temperature approaches body temperature, and evaporation by sweat and panting. Under these conditions, body temperature and metabolic heat production rise, and the animal inevitably succumbs to hyperthermia and heat stress [43].

The autonomic nervous system (ANS) can be activated through a stress response mediated by catecholamines (adrenaline and noradrenaline). This results in increased respiration and heart rate, increased body temperature, redistribution of blood flow from viscera to skin for thermoregulation, and promotion of energy utilization from body reserves [27].

\section{Conclusion}

Stress disrupt homeostasis and affect on health and performance. Heat stress is the most worrisome due to the ever-changing climate scenario. Cellular defense to heat stress is mantained by heat shock proteins (HSPs). Among the HSPs, Hsp70 has a significant role in cell thermo-tolerance and goats survival.

\section{References}

1. Suyadi, S., W.A. Septian, A. Furqon, T.E. Susilorini, M. Nasich, IOP Conf. Series: Earth and Environmental Science, 391 (2019).

2. Shaji, S., V. Sejian, M. Bagath, G.B. Manjunathareddy, E.K. Kurien, G. Varma and R. Bhatta, Biological Rhythm Research, 48, 65-83 (2017).

3. Nasich, M., Suyadi, G. Ciptadi, A. Budiarto, IOP Conf. Series: Earth and Environmental Science, 119 (2018).

4. Carvalho, G.M.C., S.R. Paiva, A.M. Araújo, A. Mariante, H.D. Blackburn, J. Anim. Sci., 93, 4629-4636 (2015).

5. Sarangi S, The Pharma Innovation J, 7, 4, 1114-1126 (2018).

6. Suyadi, S., T.E. Susilorini, W.A. Septian, A. Furqon, C.D. Nugraha, R.F. Putri, IOP Conf. Series: Earth and Environmental Science, 478 (2020).

7. Suyadi, S., S. Wahjuningsih, W.A. Septian, A.Furqon, R.F. Putri, C.D. Nugraha, 2021, IOP Conf. Series: Earth and Environmental Science, 788 (2021).

8. Chaudhary, U.B., K. Swaroop, K. Seth, P.K. Rout, G. Kumaresan, Journal of Animal Sciences, 90, 10, 1373-1376 (2020).

9. Hecker, J.G. and M. McGarvey, Cell Stress Chaperones, 16, 119-31 (2011).

10. Kishore, A., M. Sodhi, A. Sharma, U.K. Shandilya, A. Mohanty, P. Verma, S. Mann M. Mukesh, RRJVS, 2, 34- 40 (2016).

11. Deb, R., B. Sajjanar, U. Singh, S. Kumar, R. Singh, G. Sengar, A. Sharma, Gene, 536, 2,: 435-40 (2014).

12. Roh, B.H., D.H. Kim, M.K. Cho, Y.L. Park, and K.U. Whang, Ann Dermatol, 20, 4, $184-189$ (2008).

13. Qiao, L., J.X. Wu, D.Z. Qin, X.C. Liu, Z.C. Lu, L.Z. Lv, Z.L. Pan, H. Chen, and Li, G.W, Journal of Insect Science, 15, 1, 1-12 (2015). 
14. Peterson, C.W., R.T. Carter, E. Bentley, C.J. Murphy, and H.L. Chandler, Vet Ophthalmol, 19, 3, 262-266 (2016).

15. Tiwari, S., R. Thakur, and J. Shankar, Biotechnology Research International, (2015).

16. Richter, K., M. Haslbeck, and J. Buchner, Mol Cell, 40, 2, 253-266 (2010).

17. Enzolifesciences, Heat Shock Proteins and The Cellular Stress Response. http://www.Enzolifesciences.com (2010).

18. Pirkkala, L., P. Nykanen, and L. Sistonen, FASEB J., 15, 7, 1118-1131 (2001).

19. Shamovsky, I. and E. Nudler, Cell Mol. Life Sci., 65, 6, 855-861 (2008).

20. Li, Z. and P. Srivastava, Curr Protoc Immunol (2004).

21. Rovelli, G., S. Ceccobelli, F. Perini, E. Demir, S. Mastrangelo, G. Conte, F. Abeni, D. Marletta, R. Ciampolini, M. Cassandro, U. Bernabucci, E. Lasagna, Italian Journal of Animal Science, 19, 997-1014 (2020).

22. Gupta, M. and T. Mondal, Biological Rhythm Research, 1744-4179 (2019).

23. El-Tarabany, M.S., K.M. El-Bayoumi, Theriogenology, 83, 3, 444-448 (2015).

24. Silanikove, N., and N. Koluman, Small Ruminant Research, 123, 1, 27-34 (2015).

25. Marai, I.F.M., A.A.M. Haeeb, Livestock Science, 127, 2, 89-109 (2010).

26. Das, R., L. Sailo, N. Verma, P. Bharti, J. Saikia, Veterinary World, 9, 3, 260-268 (2016).

27. Gonzalez-Rivasa, P.A., S.S. Chauhana, Minh Haa, N. Feganb, F.R. Dunsheaa, R.D. Warnera, Meat Science, 192 (2020).

28. Ocak, S., O. Güney, Anadolu Tarım Bilimleri Dergisi, 25, 2, 113-119 (2010).

29. Phulia, S.K., R.C. Upadhyay, S.K. Jindal, R.P. Misra, Indian Journal Of Animal Sciences, 80, 4, 340-342 (2010).

30. Alam, M.M., M.A. Hashem, M.M. Rahman, M.M. Hossain, M.R. Haque, Z. Sobhan, M.S. Islam, Program Agriculture, 22, 1, 37-45 (2011).

31. Sharma, A.K., N. Kataria, Indian Journal Of Animal Sciences, 81, 3, 293-295 (2011).

32. Rojas-Downing, M.M., A.P. Nejadhashemi, T. Harrigan, S.A. Woznicki, Climate Risk Management, 16, 145-163 (2017).

33. Dokladny, K., O.B. Myers, P.L. Moseley, Autophagy, 11, 2, 200-2013 (2015).

34. Oberley, T.D., J.M. Swanlund, H.J. Zhang, K.C. Kregel, J. Histochem Cytochem, 56, 615-27 (2008).

35. Kim, J.N., H.S. Lee, S.H. Ryu, Y.S. Kim, J.S. Moon, C.D. Kim, I.Y. Chang, S.P. Yoon, Gut and Liver, 5, 513-20 (2011).

36. Dangi, S.S., M. Gupta, D. Maurya, V.P. Yadav, R.P. Panda, G. Singh, N.H. Mohan, S.K. Bhure, B.C. Das, S. Bag, R. Mahapatra, Trop. Anim. Health Prod., 44, 1905-1912 (2012).

37. Rout, P.K., R. Kaushik, N. Ramachandran, Cell Stress Chaperon, 21, 645-651 (2016).

38. Zulkifli, I., B. Norbaiyah, Y.W. Cheah, A.F. Soleimani, A.Q. Sazili, Y.M. Goh, M.A. Rajion, Animal, 4, 973-976 (2010).

39. Singh, K.M., S. Singh, I. Ganguly, A. Ganguly, R.K. Nachiappan, A. Chopra, H.K. Narula, Small Rumin. Res., 141, 113-117 (2016).

40. Singh, K.M., S. Singh, I. Ganguly, R.K. Nachiappan, A. Ganguly, R. Venkataramanan, A. Chopra, H.K. Narula, Cell Stress Chaperon, 22, 675-684 (2017).

41. Banerjee, D., R.C. Upadhyay, U.B. Caudhary, R. Kumar, S.V. Singh, R.G.J. Ashutosh, S. Polley, A. Mukherjee, T.K. Das, S. De, Cell Stress Chaperon, 19, 401-408 (2014).

42. Salces-Oritz, J., C. Gonzalez, M. Martinez, T. Mayoral, J.H. Calvo, M.M. Serano, BMC Evol. Biol., 15, 7 (2016).

43. Renaudeau, D., Collin, A., Yahav, S., De Basilio, V., Gourdine, J. L., \& Collier, R. J, Animal, 6, 5, 707-728 (2012). 